\begin{tabular}{c} 
International Journal of Scientific World, $5(1)(2017) 1-4$ \\
International Journal of Scientific World \\
SPC \\
Website: $\begin{array}{c}\text { www.sciencepubco.com/index.php/IJSW } \\
\text { doi: } 10.14419 / \text { ijsw. } v \text { Sil.6913 } \\
\text { Research paper }\end{array}$ \\
\hline
\end{tabular}

\title{
Mineral elements in borehole water from Northern and Western geo-political zones of Nasarawa state, Nigeria
}

\author{
Bitrus Wokhe Tukura ${ }^{1 *}$, Ibrahimn G. Igube ${ }^{2}$ \\ ${ }^{1}$ Department of Chemistry, Faculty of Natural and Applied Sciences, Nasarawa State University, Keffi, Nigeria \\ ${ }^{2}$ Department of Chemistry, Faculty of Sciences, Plateau State University, Bokkos, Nigeria \\ *Corresponding author E-mail: bittytukura@yahoo.com
}

\begin{abstract}
Mineral element contents in potable water at high concentrations may affect its quality. Concentrations of $\mathrm{Na}^{+}, \mathrm{K}^{+}, \mathrm{Ca}^{2+}$, and $\mathrm{Mg}^{2+}$ were determined in water from some boreholes in some parts of Nasarawa state, Nigeria. Levels of $\mathrm{Na}^{+}$and $\mathrm{K}^{+}$were determined using flame photometry, while $\mathrm{Ca}^{2+}$ and $\mathrm{Mg}^{2+}$ were quantified with the aid of atomic absorption spectrometry method. Concentrations of $\mathrm{Ca}^{2+}(10-$ $42 \mathrm{mg} / \mathrm{L})$ and $\mathrm{Mg}^{2+}(0.03-1.63 \mathrm{mg} / \mathrm{L})$ were relatively low in the water samples. Nasarawa Toto (NTT) recorded the highest levels of mineral elements $(0.26-10.61 \mathrm{mg} / \mathrm{L})$. Mean concentrations of $\mathrm{Na}^{+}(7.59-11.08 \mathrm{mg} / \mathrm{L})$ and $\mathrm{Mg}^{2+}(0.13-0.56 \mathrm{mg} / \mathrm{L})$ were highest and lowest respectively. The levels of mineral elements according to studied areas varied in the order of NTT > NEG (Nasarawa Eggon) > KRV (Karu) > AKW (Akwanga) > KEF (Keffi) > GRU (Garaku). The ratios of Na/K for borehole water at Wayo (3.35) and Wamba Kurmi (3.55) at Wamba (WAM) areas were the closest to the optimal ratio of 3: 1 for the control of cardiovascular diseases, while $\mathrm{Ca} / \mathrm{Mg}$ ratios were above the optimal ratio of 2:1. Total hardness levels $\left(10-48 \mathrm{mgCaCO}_{3} / \mathrm{L}\right)$ for water from the boreholes were $<60$ $\mathrm{mg} / \mathrm{L}$, therefore, classified as being soft in nature. Mineral element concentrations in water from the boreholes were within the WHO acceptable limits for drinking water.
\end{abstract}

Keywords: Water; Boreholes; Mineral Elements; Element Ratios; Political Zones.

\section{Introduction}

Water is a natural resource that is essential for the sustenance of life [1-2]. Accessibility and availability of clean water is necessary for development [3]. Groundwater resources are commonly vulnerable to pollution [2]. This has become a major environmental issue, particularly where it represents the main source of drinking water [4]. Pollution of underground water is so common in many developing countries, including Nigeria, where the security of drinking water supply has been chosen as one of the ten Millennium Development Goals [5], [6].

About $41 \%$ of Nigerians do not have access to potable water supply, with higher proportion in the rural areas [4], [7]. Also, Water Supply and Sanitation Baseline Study (WSSBS) and the UNICEF/WHO Joint Monitoring Program (JMP) have shown that Nigerian water supply has not kept pace with meeting the Millennium Development Goal (MDG) target of $75 \%$ coverage for safe drinking water.

Ground water quality varies from place to place; sometimes due to seasonal changes and geology of the area through which it moves [8], [9]. Human activities such as industrial discharges, urban activities, agriculture, groundwater plumage and disposal of waste can also affect groundwater quality [9].

Basic cations such as $\mathrm{Ca}^{2+}, \mathrm{Mg}^{2+}, \mathrm{K}^{+}$, and $\mathrm{Na}^{+}$commonly occur in surface water (Seth et al., 2014), mainly in the form of dissolved, chlorides, nitrates, sulfates, hydrogen carbonates and carbonates [10]. In natural water, minerals are the sources of cations in water, and their concentrations oscillate within wide ranges. Although ground water is generally less susceptible to contamination than surface water, it is more mineralized in its natural state. As water moves slowly through the ground it comes in contact with minerals in the soil and bedrock and becomes saturated with dissolved solids from these minerals. This dissolution process continues until chemical equilibrium is reached between the water and the minerals [10].

$\mathrm{Ca}^{2+}$ and $\mathrm{Mg}^{2+}$ ions in water are responsible for water hardness. It was proved that there is a causal relationship between drinking water hardness and morbidity and also with cardiovascular diseases [11]. Epidemiological studies have reported that water with low levels of $\mathrm{Ca}^{2+}$ and $\mathrm{Mg}^{2+}$ ions (soft water) is associated with increased morbidity and mortality from cardiovascular disease compared to hard water and water high in magnesium [12]. $\mathrm{Ca}^{2+}$ and, to a lesser extent $\mathrm{Mg}^{2+}$, prevent the absorption of some toxic elements such as $\mathrm{Pb}$ and $\mathrm{Cd}$ from the intestine into the blood, either via direct reaction leading to formation of compound that may not be absorbed or via competition for binding sites [13].

Continuous monitoring of water quality parameters is of importance because changes in the quality of water may have adverse effects on man and biota. Attention has been centered on the beneficial or protective effects of mineral elements in drinking water, with scarce information on their toxicity. Physicochemical properties of some of the boreholes have been reported [6].The study was carried out to assess mineral element quality of water from some boreholes in the western and northern geo-political zones of Nasarawa state. 


\section{Materials and methods}

\subsection{Study areas}

Water samples were collected from boreholes in the northern part of the state, which encompasses Akwanga, Wamba and Nasarawa Eggon areas, and at Garaku, Keffi, Karu, and Nasarawa Toto in the western geo-political zone (Fig. 1.)

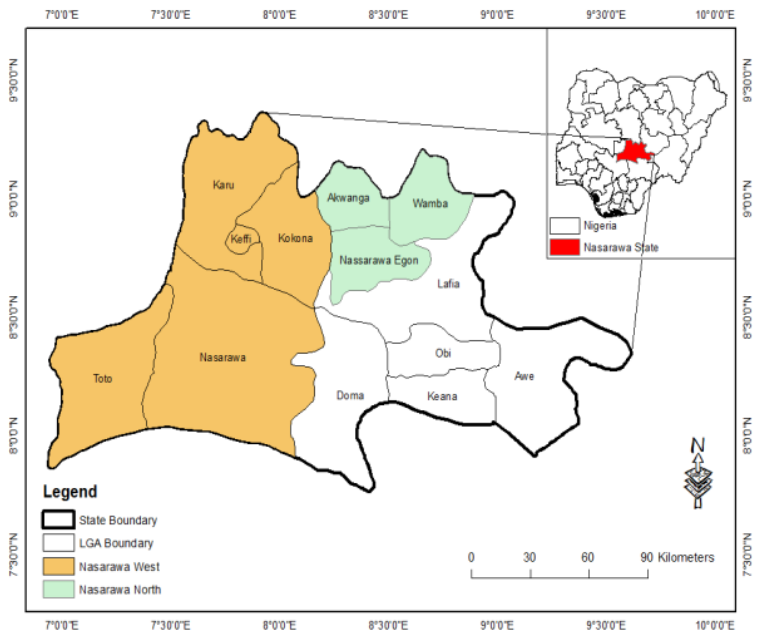

Fig. 1: Northern and Western Political Zones of Nasarawa State

\subsection{Sample collection and analysis}

The samples were collected into prewashed clean 2 liters plastic containers with screw caps during the dry period. Sampling and preservation procedures were carried out according to APHA [14] standard methods for the examination of water and wastewater. $\mathrm{Na}^{+}$and $\mathrm{K}^{+}$were determined using flame photometry, while $\mathrm{Mg}^{2+}$ and $\mathrm{Ca}^{2+}$ were quantified using atomic absorption Spectrometry method.

\section{Results and discussion}

The levels of mineral elements in water from boreholes at Akwanga (Table 1) indicated that the highest $\mathrm{Na}^{+}(11.09 \mathrm{mg} / \mathrm{L})$ and $\mathrm{K}^{+}(7.81 \mathrm{mg} / \mathrm{L})$ levels were recorded at Nuku and Nidan respectively; while the highest $\mathrm{Ca}^{2+}(4.02 \mathrm{mg} / \mathrm{L})$ and $\mathrm{Mg}^{2+}$ $(1.63 \mathrm{mg} / \mathrm{L})$ contents were observed at Township clinic . $\mathrm{Na} / \mathrm{K}$ and $\mathrm{Ca} / \mathrm{Mg}$ ratios varied from $1.01-4.02$ and $0.03-1.63$ respectively. Borehole water from Koko contained the highest level $(48 \mathrm{mg} / \mathrm{L})$ of hardness and the lowest $(10 \mathrm{mg} / \mathrm{L})$ at Tidde. $\mathrm{Na}^{+}(14.12 \mathrm{mg} / \mathrm{L})$ and $\mathrm{K}^{+}(8.21 \mathrm{mg} / \mathrm{L})$ levels were highest in Ogba at Nasarawa Eggon (Table 2). Similarly, the highest levels of $\mathrm{Ca}^{2+}(4.65 \mathrm{mg} / \mathrm{L})$ and $\mathrm{Mg}^{2+}(0.32 \mathrm{mg} / \mathrm{L}$ were recorded at Galle South. Water hardness varied from $18-42 \mathrm{mg} / \mathrm{L}$ in the zones.

Mineral element contents at Wamba (Table 3) indicated that the highest $\mathrm{Na}^{+}(14.05 \mathrm{mg} / \mathrm{L})$ and $\mathrm{K}^{+}(6.45 \mathrm{mg} / \mathrm{L})$ levels were both recorded at Zalli. However, the concentrations of $\mathrm{Ca}^{2+}(6.11$ $\mathrm{mg} / \mathrm{L})$ and $\mathrm{Mg}^{2+}(0.30 \mathrm{Mg} / \mathrm{L})$ were highest at Kwabe and Yash respectively.

$\mathrm{Ca} / \mathrm{Mg}$ and $\mathrm{Na} / \mathrm{K}$ ratios varied; with the highest levels at Wamba Kurmi (152.50) and Yash (6.48) respectively. Water total hardness varied from $18-30 \mathrm{mg} / \mathrm{L}$. Mineral contents of water from Karu (Table 4) show that the lowest levels of $\mathrm{Na}^{+}(7.21 \mathrm{mg} / \mathrm{L})$ and $\mathrm{K}^{+}$ $(2.25 \mathrm{mg} / \mathrm{L})$ were recorded at Gurku. $\mathrm{Ca}^{2+}$ and $\mathrm{Mg}^{2+}$ varied from 2.22-3.05 and 0.26-1.26 respectively. $\mathrm{Na} / \mathrm{K}$ and $\mathrm{Ca} / \mathrm{Mg}$ ratios varied according to locations, except at New Karu in Karu area. At Nasarawa Toto (Table 5), the levels of $\mathrm{Na}^{+}(13.11 \mathrm{mg} / \mathrm{L})$ and $\mathrm{K}^{+}$ $(8.54 \mathrm{mg} / \mathrm{L})$ at Chiji were maximum, while the highest concentrations of $\mathrm{Ca}^{2+}(3.40 \mathrm{mg} / \mathrm{L})$ and $\mathrm{Mg}^{2+}(0.60 \mathrm{mg} / \mathrm{L})$ were obtained at
Ukya. Total hardness varied between 20 and $32 \mathrm{mg} / \mathrm{L}$. Mean levels of macro-elements (Fig. 2) indicated that $\mathrm{Na}^{+}$levels were highest in the borehole water, while $\mathrm{Mg}^{2+}$ remained the lowest in all the studied areas. The levels of mineral elements according to studied areas varied in the order of NTT $>$ NEG $>$ KRV $>$ AKW $>$ KEF > GRU. The observed trend might be due to variations in geochemistry of the areas.

Mineral elements are essential for life. Calcium, magnesium, sodium and potassium ensure proper functioning of some important physiological mechanisms [15]. In ambient conditions, the compounds of these minerals are present in proportions that create a balanced solution. If there are additional inputs of dissolved solids to the system, the balance is altered and detrimental effects may be seen. $\mathrm{Na}^{+}$has been reported to be an important mineral maintaining electrolyte balance in humans. The levels of $\mathrm{Na}^{+}$in the borehole water predominate; which is in agreement with the results reported by Roba et al. [16]. Macro-element contents were lower than the values reported by Satyavani et al. [17], but were within the maximum permissible limits of $200 \mathrm{mg} / \mathrm{L}$ for $\mathrm{Na}^{+}$and $\mathrm{Ca}^{2+}$, $250 \mathrm{mg} / \mathrm{L}$ for $\mathrm{Mg}^{2+}$ [18] and $10 \mathrm{mg} / \mathrm{L}$ for $\mathrm{K}^{+}$[19] . The observed relatively higher levels of $\mathrm{Ca}^{2+}$ and $\mathrm{Mg}^{2+}$ for some boreholes might be due to the seepage of industrial and domestic water or due to cationic exchange [17].

$\mathrm{K}^{+}$in couple with $\mathrm{Na}^{+}$adjusts the osmotic pressure and the status of blood acidity. The 3: 1 optimal value of $\mathrm{Na} / \mathrm{K}$, gives protection against cardiovascular diseases; however, higher ratio in drinking water is associated with increased incidence of hypertension [15]. $\mathrm{Na} / \mathrm{K}$ ratios were generally lower than the optimal value. The ratio of $\mathrm{Ca} / \mathrm{Mg}$ in water is also of importance. An optimal ratio of $2: 1$ offers greater protection against cardiovascular disease [15], [16].

Table 1: Concentrations $(\mathrm{Mg} / \mathrm{L})$ of Mineral Elements and Total Hardness $\left(\mathrm{Mgcaco}_{3} / \mathrm{L}\right)$ in Water from Boreholes at Akwanga $(\mathrm{N}=3)$

\begin{tabular}{llllllll}
\hline Sites & $\mathrm{Na}^{+}$ & $\mathrm{K}^{+}$ & $\mathrm{Ca}^{2+}$ & $\mathrm{Mg}^{2+}$ & $\mathrm{Na} / \mathrm{K}$ & $\mathrm{Ca} / \mathrm{Mg}$ & $\mathrm{T} . \mathrm{H}$ \\
Takpir & 8.29 & 3.01 & 1.01 & 0.24 & 2.72 & 4.25 & 22 \\
Anjida & 8.29 & 3.09 & 3.04 & 0.24 & 2.68 & 12.67 & 22 \\
Nunku & 11.09 & 5.65 & 1.46 & 0.31 & 1.96 & 4.71 & 30 \\
$\begin{array}{l}\text { Township } \\
\text { Clinic }\end{array}$ & 6.23 & 1.37 & 4.02 & 1.63 & 4.55 & 2.47 & 32 \\
Tidde & 6.25 & 1.37 & 4.00 & 1.61 & 4.56 & 0.62 & 10 \\
Nidan & 6.34 & 7.81 & 2.09 & 0.22 & 0.81 & 9.50 & 16 \\
Koko & 9.17 & 4.00 & 3.45 & 0.17 & 2.29 & 20.29 & 48 \\
Agyaga & 8.13 & 2.01 & 2.04 & 0.03 & 4.04 & 68.00 & 20 \\
Mean & 8.00 & 3.54 & 2.64 & 0.56 & 2.95 & 15.31 & 25 \\
\pm SD & 0.23 & 2.24 & 1.16 & 0.67 & & & 11.70 \\
\hline
\end{tabular}

$\mathrm{n}=$ number of replicate determinations, T.H - Total hardness

Table 2: Concentrations $(\mathrm{Mg} / \mathrm{L})$ Of Mineral Elements Andtotal Hardness $\left(\left(\mathrm{Mgcaco}_{3} / \mathrm{L}\right)\right.$ in Water from Boreholes at Nasarawa Eggon $(\mathrm{N}=3)$

\begin{tabular}{lccccccc}
\hline Sites & $\mathrm{Na}^{+}$ & $\mathrm{K}^{+}$ & $\mathrm{Ca}^{2+}$ & $\mathrm{Mg}^{2+}$ & $\mathrm{Na} / \mathrm{K}$ & $\mathrm{Ca} / \mathrm{Mg}$ & $\mathrm{T} . \mathrm{H}$ \\
\hline Kagbu Error & 8.14 & 5.05 & 1.53 & 1.00 & 1.61 & 1.53 & 24 \\
Ogba & 14.12 & 8.21 & 1.67 & 0.18 & 1.74 & 9.30 & 20 \\
Angbaigah & 11.08 & 7.81 & 1.92 & 0.24 & 1.42 & 8.00 & 18 \\
Galle South & 7.92 & 4.65 & 4.65 & 0.32 & 1.70 & 14.53 & 18 \\
Langalaga & 14.12 & 8.13 & 1.05 & 0.19 & 1.74 & 5.53 & 42 \\
Mean & 11.08 & 6.77 & 2.16 & 0.39 & 1.64 & 7.78 & 24.50 \\
\pm SD & 3.05 & 1.76 & 1.43 & 0.35 & 0.13 & 4.80 & 11.70
\end{tabular}

$\mathrm{n}=$ number of replicate determinations, T.H - Total hardness 
Table 3: Concentrations $(\mathrm{Mg} / \mathrm{L})$ of Mineral Elements and Total Hardness $\left(\left(\mathrm{Mgcaco}_{3} / \mathrm{L}\right)\right.$ in Water from Boreholes at Wamba $(\mathrm{N}=3)$

\begin{tabular}{|c|c|c|c|c|c|c|c|}
\hline $\begin{array}{l}\text { Site } \\
\mathrm{s}\end{array}$ & $\mathrm{Na}^{+}$ & $\mathrm{K}^{+}$ & $\mathrm{Ca}^{2+}$ & $\mathrm{Mg}^{2+}$ & $\begin{array}{l}\mathrm{Na} / \\
\mathrm{K}\end{array}$ & $\mathrm{Ca} / \mathrm{Mg}$ & T.H \\
\hline & 14.0 & & & & 2.1 & 14.38 & 30 \\
\hline Zalli & 5 & 6.45 & 3.02 & 0.21 & 8 & & \\
\hline & & & & & 3.3 & 85.33 & 26 \\
\hline Wayo & 4.55 & 1.36 & 5.12 & 0.06 & $\begin{array}{l}5 \\
6.4\end{array}$ & 5.97 & 30 \\
\hline Yashi & 8.10 & 1.25 & 1.79 & 0.30 & 8 & & \\
\hline $\begin{array}{l}\text { Kwab } \\
\text { e }\end{array}$ & 6.79 & 2.66 & 6.11 & 0.06 & $\begin{array}{l}2.5 \\
5\end{array}$ & 10.83 & 18 \\
\hline $\begin{array}{l}\text { Wam- } \\
\text { ba }\end{array}$ & & & & & 3.5 & 152.50 & 25 \\
\hline Kurmi & 4.45 & 1.26 & 3.05 & 0.02 & $\begin{array}{l}3 \\
3.6\end{array}$ & 72.00 & 25.80 \\
\hline Mean & 7.59 & 2.60 & 3.82 & 0.13 & $\begin{array}{l}2 \\
1.6\end{array}$ & 61.70 & 4.92 \\
\hline$\pm \mathrm{SD}$ & 3.93 & 2.24 & 1.75 & 0.12 & 9 & & \\
\hline
\end{tabular}

$\mathrm{n}=$ number of replicate determinations, $\mathrm{T} . \mathrm{H}-$ Total hardnes

In the present study, $\mathrm{Ca} / \mathrm{Mg}$ ratio varied greatly and mostly above the optimal ratio. There is a causal relationship between drinking water hardness and morbidity by cardiovascular diseases.

High levels of $\mathrm{Ca}^{2+}$ and $\mathrm{Mg}^{2+}$ in water increase water hardness, and may lead to a decrease of the myocardial infant or sudden death risk [15]. Water total hardness levels in this study ranged between 10 and $40 \mathrm{mgCaCO}_{3} / \mathrm{L}$ which falls within the permissible limit of $150 \mathrm{mg} / \mathrm{L}$ (NIS, 2007). The values indicated that water from the boreholes might be classified as soft in nature [17]. Macro-element levels were generally highest at NTT, and the lowest at GRU; which might be attributed to variation in geochemistry of the areas.

Table 4: Concentrations $(\mathrm{Mg} / \mathrm{L})$ of Mineral Elements and Total Hardness $\left(\mathrm{MgcacO}_{3} / \mathrm{L}\right)$ in Water from Boreholes at Karu, Keffi and Garaku $(\mathrm{N}=3$

\begin{tabular}{|c|c|c|c|c|c|c|c|}
\hline Sites & $\mathrm{Na}^{+}$ & $\mathrm{K}^{+}$ & $\mathrm{Ca}^{2+}$ & $\mathrm{Mg}^{2+}$ & $\mathrm{Na} / \mathrm{K}$ & $\mathrm{Ca} / \mathrm{Mg}$ & $\begin{array}{l}\mathrm{T} . \\
\text { hard. }\end{array}$ \\
\hline \multicolumn{8}{|l|}{ Karu } \\
\hline New Karu & 10.21 & 7.11 & 3.05 & 0.26 & 1.44 & 11.73 & 26 \\
\hline Gurku & 7.21 & 2.25 & 2.22 & 1.08 & 3.20 & 2.06 & 40 \\
\hline Kurampe & 10.21 & 7.11 & 3.05 & 0.26 & 1.44 & 11.73 & 20 \\
\hline Kare & 10.36 & 6.8 & 2.88 & 1.02 & 1.52 & 2.82 & 26 \\
\hline Mean & 9.50 & 5.82 & 2.80 & 0.66 & 1.90 & 7.09 & 28 \\
\hline$\pm \mathrm{SD}$ & 1.53 & 2.38 & 0.39 & 0.46 & 1.87 & 5.37 & 8.49 \\
\hline \multicolumn{8}{|l|}{ Keffi } \\
\hline Sabon Gari & 8.26 & 1.33 & 5.30 & 0.20 & 0.14 & 26.50 & 10 \\
\hline Main Market & 7.43 & 1.25 & 6.12 & 0.26 & 5.94 & 23.54 & 34 \\
\hline Mean & 7.85 & 1.29 & 5.71 & 0.14 & 3,04 & 25.02 & 22 \\
\hline$\pm \mathrm{SD}$ & 0.59 & 0.06 & 0.58 & 0.17 & 4.10 & 2.09 & 16.97 \\
\hline \multicolumn{8}{|l|}{ Garaku } \\
\hline Arusu & 10.12 & 1.31 & 6.20 & 0.20 & 7.73 & 31.00 & 30 \\
\hline Kurame & 5.98 & 1.67 & 4.99 & 0.20 & 3.52 & 24.95 & 18 \\
\hline Kana Apawu & 7.23 & 1.35 & 2.80 & 1.01 & 5.36 & 0.03 & 20 \\
\hline
\end{tabular}

\begin{tabular}{llllllll} 
Mean & 7.78 & 1.44 & 4.60 & 0.47 & 5.54 & 18.66 & 22.67 \\
\pm SD & 2.12 & 0.20 & 1.64 & 0.47 & 2.11 & 16.42 & 6.43 \\
\hline
\end{tabular}

$\mathrm{n}=$ number of replicate determinations, T.H - Total hardness

Table 5: Concentrations $(\mathrm{Mg} / \mathrm{L})$ Of Mineral Elements And Total Hardness $\left(\left(\mathrm{Mgcaco}_{3} / \mathrm{L}\right)\right.$ In Water From Boreholes At Nasarawa Toto $(\mathrm{N}=3)$

\begin{tabular}{|c|c|c|c|c|c|c|c|c|}
\hline Sites & $\mathrm{Na}^{+}$ & $\begin{array}{l}\mathrm{K} \\
+\end{array}$ & $\mathrm{Ca}^{2+}$ & $\mathrm{Mg}^{2+}$ & $\begin{array}{l}\mathrm{Na} \\
\mathrm{K}\end{array}$ & $\begin{array}{l}\mathrm{C} \\
\mathrm{g}\end{array}$ & & T.H \\
\hline Kuru & $\begin{array}{l}12.4 \\
0\end{array}$ & 7.05 & 1.93 & & 20 & 1.76 & 9.65 & 32 \\
\hline Offu & $\begin{array}{l}10.2 \\
0\end{array}$ & 7.24 & 3.40 & & 15 & 1.41 & $\begin{array}{l}22.6 \\
7\end{array}$ & 20 \\
\hline Karmo & 8.10 & 2.45 & 2.12 & & 18 & 3.31 & $\begin{array}{l}11.7 \\
8\end{array}$ & 30 \\
\hline Chiji & $\begin{array}{l}13.1 \\
1\end{array}$ & 8.54 & 2.45 & & 31 & 1.54 & 7.90 & 28 \\
\hline Umaisha & $\begin{array}{l}10.2 \\
0\end{array}$ & 7.24 & 3.04 & 0 . & 20 & 1.41 & $\begin{array}{l}15.2 \\
0\end{array}$ & 22 \\
\hline Ukya & $\begin{array}{l}10.1 \\
0\end{array}$ & 7.15 & 2.19 & 0 . & 60 & 1.41 & 3.05 & 20 \\
\hline $\begin{array}{l}\text { Zakun } \\
\text { Bello }\end{array}$ & $\begin{array}{l}10.1 \\
5\end{array}$ & 5.43 & 1.68 & 0 . & 18 & 1.87 & 9.33 & 20 \\
\hline Mean & $\begin{array}{l}10.6 \\
1\end{array}$ & 6.44 & 6.26 & 0 . & 26 & 1.82 & $\begin{array}{l}11.3 \\
7\end{array}$ & $\begin{array}{l}24.5 \\
7\end{array}$ \\
\hline$\pm \mathrm{SD}$ & 1.66 & 2.00 & $\begin{array}{l}10.6 \\
5 \\
\end{array}$ & 6 & 16 & 0.68 & 6.20 & 5.26 \\
\hline
\end{tabular}

$\mathrm{n}=$ number of replicate determinations, T.H - Total hardness

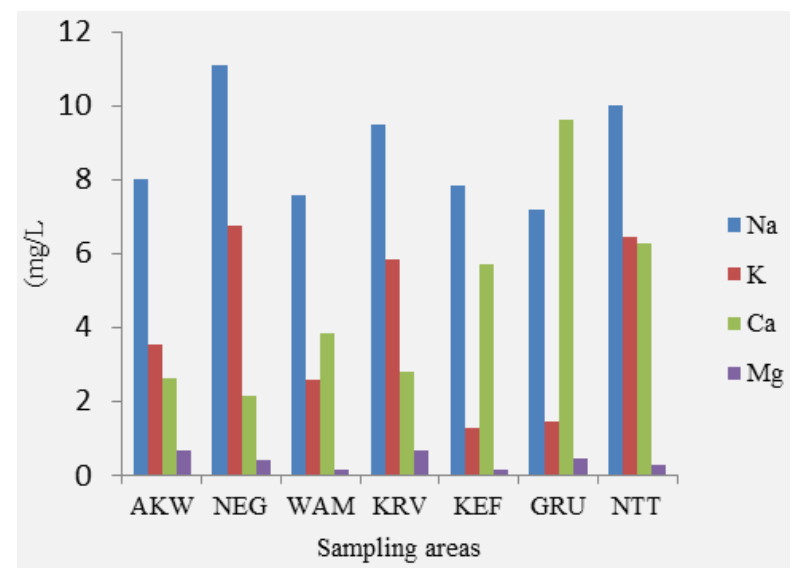

Fig. 2: Distribution of Metal Levels $(\mathrm{Mg} / \mathrm{L})$ in the Studied Areas.

\section{Conclusion}

Concentrations of $\mathrm{Na}^{+}$and $\mathrm{Mg}^{2+}$ were highest and lowest respectively across the zones. NTT recorded the highest levels of mineral elements. $\mathrm{Na} / \mathrm{K}$ ratios for borehole water at Wayo and Wamba Kurmi in Wamba (WAM) area were within the optimal ratio. $\mathrm{Ca} / \mathrm{Mg}$ values were highly above the optimal ratio, except at Gurku (2.06) in Karu (KRV) area. Total hardness level of borehole water was $<60 \mathrm{mg} / \mathrm{L}$, therefore, water from the boreholes may be classified as being soft in nature. Mineral contents were within WHO acceptable limits for drinking water. Water from the boreholes, therefore, is considered suitable for drinking and other domestic purposes.

\section{Acknowledgement}

The authors are indebted to Samuel Meme and Ayinya Mercy Ibrahim Gube for their moral support which made the research work a success. 


\section{References}

[1] Adogo LY, Ajji MA, Anyanwu NCJ, \& Ajide B (2016), Bacteriological and physico-chemical analysis of borehole water in Auta Balefi Community, Nasarawa State, Nigeria. British Microbiol. Res J. 11(4): 1-7. https://doi.org/10.9734/BMRJ/2016/22360.

[2] Obi CN, Onyegbulam AL, Ejukonemu F, \& Ubogu M (2016), Microbiological and physico-chemical analyses of borehole water samples from private schools in Umuahia Metropolis, Abia State, Nigeria. British Microbiol. Res. J. 12(1): 1-11. https://doi.org/10.9734/bmrj/2016/20136.

[3] Roba C, Roșu C, Piștea I, Ozunu A, \& Mitrofan H (2015), groundwater quality in a rural area from Buzău county, Romania. Sci. Papers Series Manag. Econ. Engin. Agricul. Rural Develop. 15(2): 305-310.

[4] Palamuleni L, \& Akoth M (2015), Physico-chemical and microbial analysis of selected borehole water in Mahikeng, South Africa. Int J. Environ. Res. Public Health, 12: 8619 - 8630. https://doi.org/10.3390/ijerph120808619.

[5] Akpor OB, \& Muchie M (2011), Challenges in meeting the MDGs: The Nigerian drinking water supply and distribution sector. J. Environ. Sci. Technol. 4: $480 \quad$ - 489. https://doi.org/10.3923/jest.2011.480.489.

[6] Tukura BW, Ibrahim EG, Onche EU, \& Ibrahim MAG (2013), Preliminary assessment of physicochemical properties of borehole water in the vicinity of public health facilities in Nasarawa State, Nigeria. IOSR J. Appl. Chem. 5(6): 55 - 63 https://doi.org/10.9790/5736-0565563.

[7] Miner, CA; Dakhin, AP; Zoakah, AI; Zaman, M, \& Bimba J (2016), Physical and microbiological quality of drinking water sources in Gwafan Community, Plateau State. Nigeria Pyrex Journal of Research in Environmental Studies, 3(1):1-6.

[8] Seth ON, Tagbor TA, \& Bernard O (2014), Assessment of chemical quality of groundwater over some rock types in Ashanti region, Ghana. Amer. J. Sci. Industrial. Res. 5: 1 - 6 .

[9] Stephen TO, \& Kennedy KA (2013), Bacteriological profile and physico-chemical quality of ground water: A case study of bore hole water sources in a rural Ghanaian community. Int. J. Current Microbiol. Appl. Sci. 2(8): 21- 40

[10] Skorbiłowicz M (2010), Concentrations of macroelements, zinc and iron ions in water of the Uppe Narew Basin, NE Poland. Polish J. Environ. Studies, 19(2): 397 - 405.

[11] Donato F, Monarca S, Premi S, \& Gelatti U (2003), Drinking water hardness and chronic degenerative diseases. Part III. Tumors, urolithiasis, fetal malformations, deterioration of the cognitive function in the aged and atopic eczema. (In Italian.) Ann Ig, 15, 57-70.

[12] Sauvant MP, \& Pepin D (2002), Drinking water and cardiovascular disease. Food Chem. Toxicol. 40: 1311-1325. https://doi.org/10.1016/S0278-6915(02)00081-9.

[13] Hopps HC, \& Feder G L (1986). Chemical qualities of water that contribute to human health in a positive way. Sci. Total Environ. 54: 207-216. https://doi.org/10.1016/0048-9697(86)90266-4.

[14] APHA (1998), Standard Methods for Examination of water and wastewater. 19th ed., American Public Health Association, Washington, DC, USA.

[15] Nicoleta DV, \& Vieru NP (2010), Levels of magnesium, calcium and other inorganic compounds in water of the wells in rural areas of Botossani country. Present Environment \& Sustainable Development, NR. 4, 139 - 406.

[16] Satyavani CH, Venkateswararao B, \& Machi PVSR (2013), Physicochemical and microbial analysis of ground water near municipal dump site for quality evaluation. Int. J. Bioassays, 1139 -1144.

[17] WHO (2006), International Standards for Drinking Water, 3rd Edition Geneva, 346-385

[18] WHO (2011), Guidelines for drinking water quality. 4th ed. 20 Avenue Appia, 1211 Geneva 27, Switzerland.

[19] Nigerian Industrial standard (NIS) (2007). Nigerian standard for drinking water quality. ICS 13.060.20. 